\title{
Sporothrix schenckii cell wall peptidorhamnomannans
}

\section{Leila M. Lopes-Bezerra*}

Laboratório de Micologia Celular e Proteômica, Instituto de Biologia Roberto Alcantara Gomes, Universidade do Estado do Rio de Janeiro, Rio de Janeiro, Brazil

\section{Edited by:}

Marcio Rodrigues, Federal University of Rio de Janeiro, Brazil

\section{Reviewed by:}

Slawomir Milewski, Gdansk

University of Technology, Poland

Everardo López-Romero, Universidad

de Guanajuato, Mexico

*Correspondence:

Leila M. Lopes-Bezerra, Laboratório

de Micologia Celular e

Proteômica/IBRAG, Universidade do

Estado do Rio de Janeiro, Rua São

Francisco Xavier 524 PHLC sl. 501D,

CEP 20550-013 Rio de Janeiro, Brazil.

e-mail: leila@uerj.br;

leila.lopes_bezerra@pq.cnpq.br
This mini-review article is dedicated to clarifying certain important biochemical aspects of Sporothrix schenckii cell wall peptidorhamnomannans. Cell wall components involved in the host interaction such as antigens as well as a gp70 adhesin are important molecules present on the surface of the yeast parasitic phase. Other structural glycoconjugates present on the fungus cell surface are also described here. Knowledge of the fine structure of carbohydrate epitopes expressed on the surface in both morphological phases of $S$. schenckii permitted the development of non-invasive immunochemical methods to diagnose human and feline sporotrichosis.

Keywords: Sporothrix schenckii, cell wall, antigens, gp70, peptidorhamnomannan

\section{GENERAL ASPECTS OF S. SCHENCKII}

Sporotrichosis is a subcutaneous mycosis caused by the dimorphic fungus Sporothrix schenckii. This disease has several clinical forms and, until now, no clear scientific evidence can explain the occurrence of cutaneous disseminated and/or extracutaneous forms of sporotrichosis in immunocompetent patients (Lima Barros et al., 2003; Schubach et al., 2008). These clinical observations indicate that besides the immunological background of the host, other factors associated with the pathogen can impair the clinical manifestations of this disease, such as virulence factors (i.e., adhesins) and antigenic molecules. Some of these factors of S. schenckii will be briefly discussed in this review article, focusing on the fungus surface.

Another important feature that should be highlighted is the recent description of several genotypes indicating that $S$. schenckii is a complex of cryptic species, denominated the S. schenckii complex (Marimon et al., 2006, 2007). Within this complex, at least five species are considered of interest due to their pathogenic potential (Arrillaga-Moncrieff et al., 2009). Among these, S. globosa have already been associated with human cases (Oliveira et al., 2010) and S. brasiliensis with feline sporotrichosis (Lopes-Bezerra L. M., unpublished results) in Brazil. The genome project of two pathogenic species, S. schenckii and S. brasiliensis, are currently under development (Felipe M. S. and Lopes-Bezerra L. M., personal communication) and will bring new insights regarding virulence factors and other relevant biological aspects of these two pathogenic species, which can be further associated with noteworthy clinical and epidemiological aspects of sporotrichosis.

Subcutaneous fungal infections are usually chronic conditions. They often begin after the skin has been pierced following an injury of some kind, since this allows infectious fungi to penetrate the skin and establish themselves inside the host. Eventually, a subcutaneous infection like sporotrichosis can evolve to severe systemic or disseminated forms. In this rather complicated puzzle, the first step for a pathogen to succeed is its capacity to adhere to and colonize host tissues. The binding of pathogen-associated molecular patterns (PAMPs) as cell wall sugar polymers and proteins, to pattern recognition receptors (PRRs) on innate immune cells triggers the activation of the immune system (Bourgeois et al., 2010; Latgé, 2010). Additionally, adhesion molecules expressed on the fungus cell surface can mediate their interaction with host cells and extracellular matrix components (Tronchin et al., 2008).

One of the well known cell wall components of $S$. schenckii is the peptidorhamnomannan. This glycopeptide or glycoconjugate is a complex of molecules with a wide range of molecular weights that are hard to purify as individual components (Lima and Lopes-Bezerra, 1997). This cell wall peptidorhamnomannan fraction (CWPR) can be recognized by IgG antibodies present in patient sera (Lloyd and Bitoon, 1971; Penha and Lopes-Bezerra, 2000) and by host cell receptors and matricial proteins (Lima et al., 2001; Figueiredo et al., 2004). Another interesting cell wall component, also present in the fungus culture filtrate, is a $70-\mathrm{kDa}$ antigen (Lima and Lopes-Bezerra, 1997; Nascimento and Almeida, 2005). Furthermore, several groups have reported evidence of the role of gp70 as an important adhesin that can mediate fungus adhesion to host tissues and to matricial proteins of the basal lamina (López-Romero et al., 2011).

\section{CELL WALL GLYCOCONJUGATES}

Sporothrix schenckii has two morphological phases: a mycelial saprophytic form and a parasitic yeast-like form. Alkali-soluble and -insoluble glucans were detected in both morphological phases of this fungus. Alkali-soluble glucans of the yeast form of $S$. schenckii are linked by $\beta(1,3), \beta(1,6)$, and $\beta(1,4)$ bonds at 44 , 28 , and $28 \%$, respectively. Insoluble glucans contain 66,29 , and $5 \%$, respectively, of $\beta(1,3), \beta(1,6)$, and $\beta(1,4)$ bonds. No variations in $\beta$-glucan composition were correlated with the fungus morphological transition (Previato et al., 1979). Furthermore, there 
is no evidence in the literature concerning the presence of an $\alpha$ glucan on the fungus surface, similar to that described for other dimorphic fungi.

The cell wall peptidorhamnomannan is composed of $33.5 \%$ rhamnose, $57 \%$ mannose, and $14.2 \%$ protein and was characterized in the yeast-phase of S. schenckii (Lloyd and Bitoon, 1971). In addition to rhamnose and mannose, polysaccharides containing galactose have also been identified on the surface of this fungus. A similar component containing rhamnose and mannose was detected in a fraction isolated from the culture filtrate of $S$. schenckii (Ishizaki, 1970). This culture filtrate glycopeptide was also shown to be antigenic and its antigenicity varied according to the rhamnose:mannose molar ratio, which is influenced by the culture conditions (Takata and Ishizaki, 1983).

Another intriguing finding was the observation that S. schenckii peptidorhamnomannans reacted with the carbohydrate-binding protein Concanavalin A (lectin ConA), but the rhamnomannans extracted by hot alkali treatment was non-reactive (Travassos et al., 1977). These findings did not confirm the preliminary structural evidence indicating the presence of mannose residues at non-reducing ends of the carbohydrate moiety of peptidorhamnomannan (Lloyd and Bitoon, 1971). Further biochemical studies verified that ConA reactivity was associated with the presence of $O$-glycosidically linked chains in the CWPR structure (LopesAlves et al., 1992). The O-linked oligosaccharides had a common internal core of $\alpha$-D-Man $1 \rightarrow 2 \alpha$-D-Man (illustrated in Figure 1 ) and the 2- $O$ substituted mannose residue was identified as the lectin binding domain present on the fungus cell surface

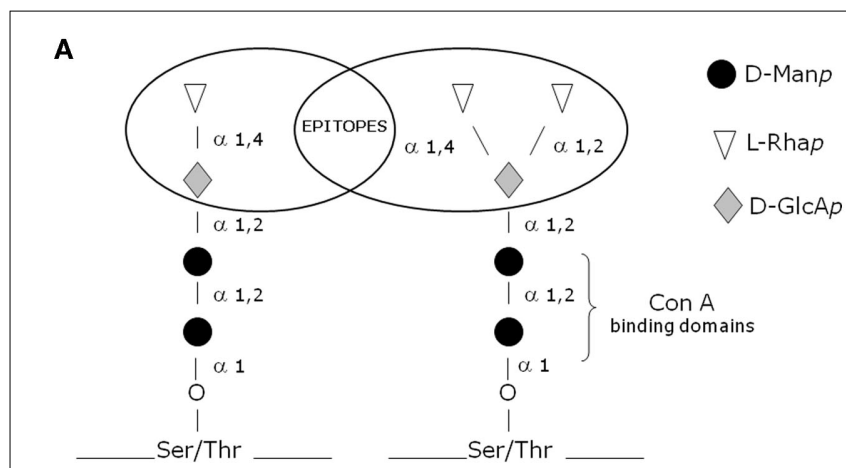

B

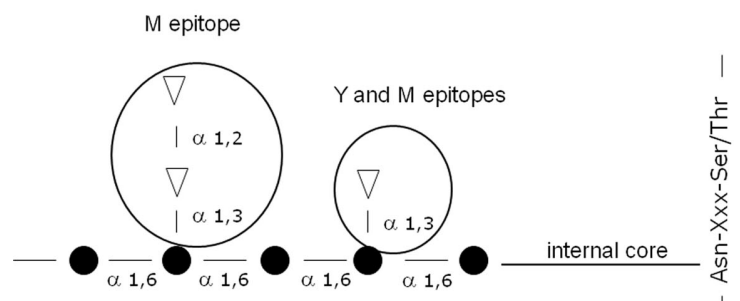

FIGURE 1 | (A,B) Schematic representation showing the general structure of the main antigenic epitopes and ConA-binding sites described on the cell wall peptidorhamonomannan of both the yeast $(\mathrm{Y})$ and mycelial $(\mathrm{M})$ phases of $S$. schenckii.
(Lopes-Alves et al., 1992). Immunocytochemical analysis of antigens in the outermost layer of yeast cells of S. schenckii revealed labeling of these antigens by polyclonal antibodies colocalized with regions reactive with ConA (Castillo et al., 1990).

The peptidorhamnomannan fraction described by Lloyd and Bitoon (1971) reacted with sera from patients with sporotrichosis. The main carbohydrate epitopes identified in the $\mathrm{N}$ and $\mathrm{O}$-glycosidically linked chains of CWPR are illustrated in Figures 1A,B. In addition, an enriched glycopeptide cell wall fraction inhibited the adhesion of the yeast-phase of S. schenckii to extracellular matrix proteins, suggesting the presence of adhesins on the surface of this pathogen (Lima et al., 2001, 2004). In addition to rhamnose and mannose, polysaccharides containing galactose have been identified on the surface of this fungus, suggesting the presence of a cell wall galactomannan (Mendonça et al., 1976; Mendonça-Previato et al., 1980). A peptidorhamnogalactan has previously been isolated from yeast-like cells (Nakamura, 1976). Glucuronic acid residues have been described in an acidic fraction of rhamnomannans from S. schenckii (Gorin et al., 1977). In addition, the $O$-glycosidic chains showed important antigen determinants involving $\alpha$-D-glucuronic acid residues mono- and disubstituted by terminal non-reducing rhamnose residues (Figure 1A; Lopes-Alves et al., 1994).

Interestingly, a structurally similar cell surface peptidorhamnomannan was described in the pathogenic fungus Pseudallescheria boydii and, this peptidopolysaccharide also presented $O$-linked chains (Pinto et al., 2005). Similarly to $S$. schenckii, the rhamnose containing structures appear to be immunodominant epitopes.

\section{S. SCHENCKII ANTIGENS}

Antigens isolated from both the culture filtrate and the cell wall have been used for intradermal tests in guinea pigs and humans (Nielsen, 1968). Sporotrichin tests, however, have yielded falsepositive results in individuals with no history of sporotrichosis (Schneidau et al., 1964). Furthermore, antigens isolated from the culture filtrate are highly heterogeneous (Takata and Ishizaki, 1983).

Since the cell wall is the surface structure of the fungal cell and therefore mediates the relation with the host, it represents an important source of antigens. Several studies have been conducted with the objective of isolating and identifying antigens on the cell wall of $S$. schenckii. The evidence that the $O$-linked tetra- and pentasaccharides carry important antigenic epitopes (Table 1), $\alpha$-L-Rhap $1 \rightarrow 2 \alpha$-D-GLcA $p$ and $\alpha$-L-Rhap $1 \rightarrow 4$

\section{Table 1 | Maximum inhibition (\%) of S. schenckii peptidorhamnomannan immunoprecipitation with its derived $O$-linked oligosaccharides (at $1 \mu \mathrm{mol}$ ).}

\begin{tabular}{lc} 
Oligosaccharide & \% In \\
\hline Trisaccharide & 28 \\
Tetrasaccharide & 63 \\
Pentasaccharide & 82 \\
Tri pentasaccharide & 95
\end{tabular}

Adapted from Lopes-Alves et al. (1994). 
$\alpha$-D-GlcA $p$ (Figure 1), which had not been described in other species, suggested that they could be used as potential markers for serodiagnosis (Lopes-Alves et al., 1994). Using the recognition and binding capacity of these CWPR O-glycosidic chains to the lectin ConA, Lima and Lopes-Bezerra (1997) purified a cell wall ConA-binding fraction, called $\operatorname{SsCBF}$ ( S. schenckii ConAbinding fraction). In ELISA assays using human sera (gold standard), this antigenic fraction was recognized by IgG antibodies present in the sera of patients with all clinical forms of sporotrichosis (Bernardes-Engemann et al., 2005) and this recognition was specifically blocked by the purified $O$-linked tetra- and pentasaccharides (Penha and Lopes-Bezerra, 2000). This serological test has also been useful for therapeutic follow-up of patients (Bernardes-Engemann et al., 2005). Another serological ELISA test was proposed in the literature (Almeida-Paes et al., 2007), based on a culture filtrate antigenic preparation. The ELISA tests described in the current literature showed values of specificity and sensibility ranging from 80 to $95 \%$. Another recent study confirmed that the Ss CBF antigen could also be useful for the serodiagnosis of feline sporotrichosis (Fernandes et al., 2011).

In conclusion, non-invasive diagnostic tools are available to promptly diagnose not only the classic lymphocutaneous or fixed cutaneous forms of sporotrichosis, but also the disseminated and atypical forms of this disease or unresolved cases that are negative according to the routine mycological test.

\section{S. SCHENCKII gp70}

In the cell wall $S s \mathrm{CBF}$ antigenic fraction three main antigens with approximate molecular weights of 84 (gp84), 70 (gp70), and $58 \mathrm{kDa}$ which reacted with a rabbit anti-S. schenckii serum were identified (Lima and Lopes-Bezerra, 1997). 2D-immunoblotting with anti-S. schenckii antibodies had shown that a $70-\mathrm{kDa}$

\section{REFERENCES}

Almeida-Paes, R., Pimenta, M. A, Pizzini, C. V., Monteiro, P. C., Peralta, J. M., Nosanchuk, J. D., and Zancopé-Oliveira, R. M. (2007). Use of mycelial-phase Sporothrix schenckii exoantigens in an enzymelinked immunosorbent assay for diagnosis of sporotrichosis by antibody detection. Clin. Vaccine Immunol. 14, 244-249.

Arrillaga-Moncrieff, I., Capilla, J., Mayayo, E., Marimon, R., Mariné, M., Gené, J., Cano, J., and Guarro, J. (2009). Different virulence levels of the species of Sporothrix in a murine model. Clin. Microbiol. Infect. 15, 651-655.

Bernardes-Engemann, A. R., Costa, R. C., Miguens, B. R., Penha, C. V., Neves, E., Pereira, B. A., Dias, C. M., Mattos, M., Gutierrez, M. C., Schubach, A., Oliveira Neto, M. P., Lazéra, M., and Lopes-Bezerra, L. M. (2005). Development of an enzymelinked immunosorbent assay for the serodiagnosis of several clinical forms of sporotrichosis. Med. Mycol. 43, 487-493.
Bourgeois, C., Majer, O., Frohner, I. E., Tierney, L., and Kuchler, K. (2010). Fungal attacks on mammalian hosts: pathogen elimination requires sensing and testing. Curr. Opin. Microbiol. 13, 401-408.

Castillo, M. C., Tapia, F. J., and Arciniegas, E. (1990). Ultrastructural localization of specific surface antigens in the dimorphic fungus Sporothrix schenckii. J. Med. Vet. Mycol. 28, 91-94.

Fernandes, G. F., Lopes-Bezerra, L. M., Bernardes-Engemann, A. R., Schubach, T. M., Dias, M. A., Pereira, S. A., and Camargo, Z. P. (2011). Serodiagnosis of sporotrichosis infection in cats by enzymelinked immunosorbent assay using a specific antigen, SsCBF, and crude exoantigens. Vet. Microbiol. 147, 445-449.

Figueiredo, C. C., Lima, O. C., Carvalho, L., Lopes-Bezerra, L. M., and Morandi, V. (2004). The in vitro interaction of Sporothrix schenckii with human endothelial cells is modulated by cytokines and involves endothelial surface

glycoprotein was the major antigen detected in the cell wall of the mycelial and the yeast-like phases of S. schenckii and, a $60-\mathrm{kDa}$ antigenic glycoprotein was present only on the surface of yeast-like cells (Ruiz-Baca et al., 2011).

Further studies had shown that sera from mice infected with S. schenckii had IgG1 and IgG3 antibodies reacting with a gp70 antigenic component present in the fungus culture filtrate (Nascimento and Almeida, 2005). A monoclonal antibody was raised against the secreted gp70 antigen, mAb P6E7. This monoclonal antibody had a protective effect in vivo by passive immunization of mice infected with S. schenckii (Nascimento et al., 2008). Besides, the secreted gp70 antigen was also shown to be expressed on the cell wall of the yeast-like phase of several clinical isolates of $S$. schenckii (Teixeira et al., 2009). This antigenic glycoprotein seems to have other important functions. There is strong evidence for its role as an adhesin which mediates $S$. schenckii interaction with the extracellular matrix protein fibronectin and also, adhesion of this fungus to the dermis of mouse tails (Ruiz-Baca et al., 2009; Teixeira et al., 2009). The co-localization on the yeast cell surface of a fibronectin adhesin and the mAb P6E7 antibody was confirmed by confocal microscopy, suggesting that the gp70 exoantigen and the cell wall protein with apparent $\mathrm{MW}$ of $70 \mathrm{kDa}$ are similar components (Teixeira et al., 2009).

The purified gp70 exhibited a pI of 4.1 and about $5.7 \%$ of its molecular mass was contributed by $N$-linked glycans with no evidence for $O$-linked oligosaccharides (Ruiz-Baca et al., 2009).

\section{ACKNOWLEDGMENTS}

Leila M. Lopes-Bezerra is a research fellow of the Conselho Nacional de Desenvolvimento Científico e Tecnológico (CNPq) and the Fundação de Amparo a Pesquisa do Estado do Rio de Janeiro (FAPERJ).

molecules. Microb. Pathog. 36, 177-188.

Gorin, P. A. J., Haskins, R. H., Travassos, L. R., and Mendonça-Previato, L. (1977). Further studies on the rhamnomannans and acidic rhamnomannans of Sporothrix schenckii and Ceratocystis stenoceras. Carbohydr. Res. 55, 21-33.

Ishizaki, H. (1970). Some antigenic substances from culture filtrate of Sporothrix schenckii. Jpn. J. Dermatol. B 80, 16-23.

Latgé, J. P. (2010). Tasting the fungal cell wall. Cell. Microbiol. 12, 863-872.

Lima, O. C., Bouchara, J. P., Renier, G., Marot-Leblond, A., Chabasse, D., and Lopes-Bezerra, L. M. (2004). Immunofluorescence and flow cytometry analysis of fibronectin and laminin binding to Sporothrix schenckii yeast cells and conidia. Microb. Pathog. 37, 131-140.

Lima, O. C., Figueiredo, C. C., Previato, J. O., Mendonça-Previato, L., Morandi, V., and Lopes-Bezerra, L. M. (2001). Involvement of fungal cell wall components in adhesion of Sporothrix schenckii to human fibronectin. Infect. Immun. 69, 6874-6880.

Lima, O. C., and Lopes-Bezerra, L. M. (1997). Identification of a concanavalin A-binding antigen of the cell surface of Sporothrix schenckii. J. Med. Vet. Mycol. 35, 167-172.

Lima Barros, M. B, de Oliveira Schubach, A., Galhardo, M. C., Schubach, T. M., dos Reis, R. S., Conceição, M. J., and do Valle, A. C. (2003). Sporotrichosis with widespread cutaneous lesions: report of 24 cases related to transmission by domestic cats in Rio de Janeiro, Brazil. Int. J. Dermatol. 42, 677-681.

Lloyd, K. O., and Bitoon, M. A. (1971). Isolation and purification of a peptido-rhamnomannan from the yeast form of Sporothrix schenckii. Structural and immunochemical studies. J. Immunol. 107, 663-671.

Lopes-Alves, L. M., Mendonça-Previato, L., Fournet, D., Degant, P., and Previato, J. O. (1992). O-glycosidically linked oligosaccharides from peptidorhamnomannans of Sporothrix schenckii. Glycoconj. J. 9, 75-81. 
Lopes-Alves, L. M., Travassos, L. R., Previato, J. O., and Mendonça-Previato, L. (1994). Novel antigenic determinants from peptidorhamnomannans of Sporothrix schenckii. Glycobiology 4, 281-288.

López-Romero, E., Reyes-Montes Mdel, R., Pérez-Torres, A., Ruiz-Baca, E., Villagómez-Castro, J. C., MoraMontes, H. M., Flores-Carreón, A., and Toriello, C. (2011). Sporothrix schenckii complex and sporotrichosis, an emerging health problem. Future Microbiol. 6, 85-102.

Marimon, R., Cano, J., Gené, J., Sutton, D. A., Kawasaki, M., and Guarro, J. (2007). Sporothrix brasiliensis, S. globosa, and $S$. mexicana, three new Sporothrix species of clinical interest. J. Clin. Microbiol. 45, 3198-3206.

Marimon, R., Gené, J., Cano, J., Trilles, L., Dos Santos Lazéra, M., and Guarro, J. (2006). Molecular phylogeny of Sporothrix schenckii. J. Clin. Microbiol. 44, 3251-3256.

Mendonça, L., Gorin, P. A. J., Lloyd, K. O., and Travassos, L. R. (1976). Polymorphism of Sporothrix schenckii surface polysaccharides as a function of morphological differentiation. Biochemistry 15, 2423-2431.

Mendonça-Previato, L., Gorin, P. A. J., and Travassos, L. R. (1980). Galactose-containing polysaccharides from the human pathogen to Sporothrix schenckii. Infect. Immun. 29, 934-939.

Nakamura, Y. (1976). Purification and isolation of a biologically active peptide-rhamnogalactan from to
Sporothrix schenckii. J. Dermatol. 3, 25-29.

Nascimento, R. C., and Almeida, S. R. (2005). Humoral immune response against soluble and fractionate antigens in experimental sporotrichosis. FEMS Immunol. Med. Microbiol. 43, 241-247.

Nascimento, R. C., Espíndola, N. M., Castro, R. A., Teixeira, P. A., Loureiro y Penha, C. V., LopesBezerra, L. M., and Almeida, S. R. (2008). Passive immunization with monoclonal antibody against a $70-\mathrm{kDa}$ putative adhesin of Sporothrix schenckii induces protection in murine sporotrichosis. Eur. J. Immunol. 38, 3080-3089.

Nielsen, H. S. Jr. (1968). Biological properties of skin test antigens of yeast form Sporotrichum schenckii. J. Infect. Dis. 118, 173-180.

Oliveira, M. M., Almeida-Paes, R., Medeiros Muniz, M., Lima Barros, M. B., Galhardo, M. C., and Zancope-Oliveira, R. M. (2010). Sporotrichosis caused by Sporothrix globosa in Rio de Janeiro, Brazil: case report. Mycopathologia 169, 359-363.

Penha, C. V., and Lopes-Bezerra, L. M. (2000). Concanavalin A-binding cell wall antigens of Sporothrix schenckii: a serological study. Med. Mycol. 38, $1-7$.

Pinto, M. R., Gorin, P. A., Wait, R., Mulloy, B., and Barreto-Bergter, E. (2005). Structures of the O-linked oligosaccharides of a complex glycoconjugate from Pseudallescheria boydii. Glycobiology 15, 895-904.
Previato, J. O., Gorin, P. A. J., Haskins, R. H., and Travassos, L. R. (1979). Soluble and insoluble glucans from different cell types of Sporothrix schenckii. Exp. Mycol. 3, 92-105.

Ruiz-Baca, E., Mora-Montes, H. M., López-Romero, E., Toriello, C., Mojica-Marín, V., and Urtiz-Estrada, N. (2011). 2D-immunoblotting analysis of Sporothrix schenckii cell wall. Mem. Inst. Oswaldo Cruz 106 248-250.

Ruiz-Baca, E., Toriello, C., Perez-Torres, A., Sabanero-Lopez, M., VillagomezCastro, J. C., and Lopez-Romero, E. (2009). Isolation and some properties of a glycoprotein of 70 $\mathrm{kDa}(\mathrm{Gp} 70)$ from the cell wall of Sporothrix schenckii involved in fungal adherence to dermal extracellular matrix. Med. Mycol. 47, 185-196.

Schneidau, J. D., Lamar, L. M., and Hairston, M. A. (1964). Cutaneous hypersensitivity to sporotrichin in Louisiana. JAMA 188, 371-373.

Schubach, A., Barros, M. B., and Wanke, B. (2008). Epidemic sporotrichosis. Curr. Opin. Infect. Dis. 21, 129-133.

Takata, M., and Ishizaki, H. (1983). Correlations among culture times, sugar composition and biological activities of Sporothrix schenckii antigens. Mycopathologia 84, 31-39.

Teixeira, P. A., Castro, R. A., Nascimento R. C., Tronchin, G., Perez-Torres, A, Lazéra, M., Almeida, S. R., Bouchara, J. P., Loureiro y Penha, C. V., and Lopes-Bezerra, L. M. (2009). Cell surface expression of adhesins for fibronectin correlates with virulence in Sporothrix schenckii. Microbiology 155, 3730-3738.

Travassos, L. R., Souza, W., MendonçaPreviato, L., and Lloyd, K. O. (1977). Location and biochemical nature pf surface components reacting with concanavalin A in different cell types of Sporothrix schenckii. Exp. Mycol. 1, 293-305.

Tronchin, G., Pihet, M., Lopes-Bezerra, L. M., and Bouchara, J. P. (2008). Adherence mechanisms in human pathogenic fungi. Med. Mycol. 46, 749-772.

Conflict of Interest Statement: The author declares that the research was conducted in the absence of any commercial or financial relationships that could be construed as a potential conflict of interest.

Received: 28 September 2011; paper pending published: 13 October 2011 accepted: 22 November 2011; published online: 21 December 2011.

Citation: Lopes-Bezerra LM (2011) Sporothrix schenckii cell wall peptidorhamnomannans. Front. Microbio. 2:243. doi: 10.3389/fmicb.2011.00243 This article was submitted to Frontiers in Fungi and Their Interactions, a specialty of Frontiers in Microbiology.

Copyright (C) 2011 Lopes-Bezerra. This is an open-access article distributed under the terms of the Creative Commons Attribution Non Commercial License, which permits non-commercial use, distribution, and reproduction in other forums, provided the original authors and source are credited. 